\title{
THE EFFECT OF DIFFERENT BLOODINESS LEVEL ON LATVIAN BROWN COW PRODUCTIVITY
}

\author{
Lāsma CIELAVA, Institute of Agrobiotechnology, Latvian University of Agriculture Lielā iela 2, Jelgava, LV-3001 Latvia, \\ lasma.cielava@llkc.lv (corresponding author) \\ Solvita PETROVSKA, Institute of Agrobiotechnology, Latvian University of Agriculture Lielā iela 2, Jelgava, LV-3001 Latvia, \\ solvitapetrovska@inbox.lv \\ Daina JONKUS, Institute of Agrobiotechnology in Latvia University of Agriculture, Lielā iela 2, LV-3001 Jelgava, Latvia, \\ daina.jonkus@1lu.lv \\ Lìga PAURA, Institute of Agrobiotechnology in Latvia University of Agriculture, Lielā iela 2, LV-3001 Jelgava, Latvia, \\ liga.paura@1lu.lv
}

Latvian brown (LB) cow breed is economically most important livestock breed in Latvia. In last 5 years in Latvian farms rapidly increases Holstain black and white cow population, however LB breed cows is more resistant against environment and climate changes than relatively new Holstain breed cows. More resistant is genetic resource LB cows. In study was observed data from Latvian Agriculture data center about Latvian brown (LB) cows with different breed blood admixture. Cows, included in data base was born in time period from 2003-2007 year and closed at least 1 full lactation. The aim of the study was to determine how different amount of Latvian brown cow bloodiness affects cow productivity and longevity. Latvian brown cow milk yield significantly lower $(\mathrm{p}<0.05)$ was in first lactation $(4826.1 \mathrm{~kg})$, but it increased until fifth lactation $(5891.8 \mathrm{~kg})$. Opposite situation was occurred with milk dry matter content, milk fat content significantly higher was in first lactation, but until 5th lactation it decreased by $0.84 \%$, similar situation was occurred with milk protein content. Significantly highest milk yield grouped by dominant breed bloodines was observed in group with Brown Swiss bloodiness $(4887.3 \pm 26.3 \mathrm{~kg}$; p <0.05), but highest protein content in genetic resources group $(4.31 \pm 0.02 \%)$. Average lifespan in LB cow population was 2463.0 days (in average 6.7 years or about 5 lactations.

Keyword: cow longevity, milk yield, parity

\section{INTRODUCTION}

Breeding and managing dairy cows for high productivity damages their health and decreased productivity life. The culling reasons in different farms vary and usually are connected with mastitis, laminitis, low milk productivity and other different factors including farm management and animal breeding (Bascom and Young, 1998; Lucy, 2001). Mastitis is the most frequent and costly disease in dairy cows, and economic losses can be attributed to both clinical and subclinical disease (Caraviello et al., 2005).

According by previous studies the breed is significant factor which affect milk yield and composition. Red cow group cows are more likely give smaller amount of milk with higher milk components (milk fat and protein content), but black and white cows will be more productive, but with poorer health. Holstein breed produce more milk than other breed, for example, Brown Swiss and Simmental, but milk composition better was in Brown Swiss cow breed (Penasa et al., 2014). Different studies show that native breeds (genetic resources) produce less milk in 305 day lactation than Holstein (Saveli, Voore, 2006). The milk productivity is one of the reasons why productive life for genetic resources is longer. As were found scientists from Florida, about $20 \%$ of cows were culled within 365 days after first calving, but $50 \%$ was culled after 827 days (the median productive life). Only $10 \%$ of the cows were still in the herd after 1580 days. In Latvia $80 \%$ of all produced milk was collected from farms with 1-20 cows which classifies as small farms. In smaller farms, as shown in studies, the length of productive life is longer, but there are not significant difference between lifetime milk productivity (Vries, 2008). Similar trend as in other scientific papers was found in Latvia, productive life of Latvian Brown is longer in small farms and it resulting with highest lifetime productivity (Cielava et al., 2014).

In some cases farmers make a focus on the great milk yield in early lactation stage and cull cows before they are capable of releasing its maximal productivity (Roxstrom, Strandberg, 2002). Milk fat and protein content increases in following lactation, for example, fat content of Holstein were $3.68 \%$ in $1^{\text {st }}$ lactation, but it increased to $3.92 \%$ in $5^{\text {th }}$

Copyright (C) 2015 The Authors. Published by Aleksandras Stulginskis University. This is an open-access article distributed under the terms of the Creative Commons Attribution License (CC-BY 4.0), which permits unrestricted use, distribution, and reproduction in any medium, provided the original author and source are credited. 
lactation. This fact is very important if farm is interested in increasing cow longevity (Yu et al., 2011). One of factors that affect the productivity of dairy cows is parity - as older cow gets, as milk yield increases (Sklan et al., 1994).

The Latvian Brown (LB) and Latvian Blue cow breeds are genetic resources in Latvia and these breed cows are in small count. In Latvia are common to inseminate Latvian brown cow breed cows with different breed (related or nonrelated) bull semen. Most commonly for milk producing are selected Holstein Black and White, Danish Red, Swedish Red and White and Latvian Brown with different breed blood. Milk yield of Latvian Brown and Latvian Blue was lower in standardlactation compared with others dairy cow breeds in Latvia (recording year 2014). Latvian genetic resources have great potential to live more than 10 years (in many European countries cows are culling after $2^{\text {nd }}$ or $3^{\text {rd }}$ lactation) and produce quality milk.

\section{MATERIALS AND METHODS}

In study was observed data from Latvian Agriculture data center about Latvian brown (LB) cows with different breed blood admixture. Cows, included in data base was born in time period from 2003-2007 year and closed at least 1 full lactation.

In data base was obtained data about Latvian brown cow productivity - milk yield, milk fat content and milk protein content - and cow longevity - date of birth and date of culling. In all together data was collected about 34152 culled and 17455 live Latvian brown cows. Also was obtained data about Latvian brown cow breed bloodline structure (bloodiness). (Figure 1).

In data base was obtained data overall about 131235 closed lactations which was distributed in 6 different groups

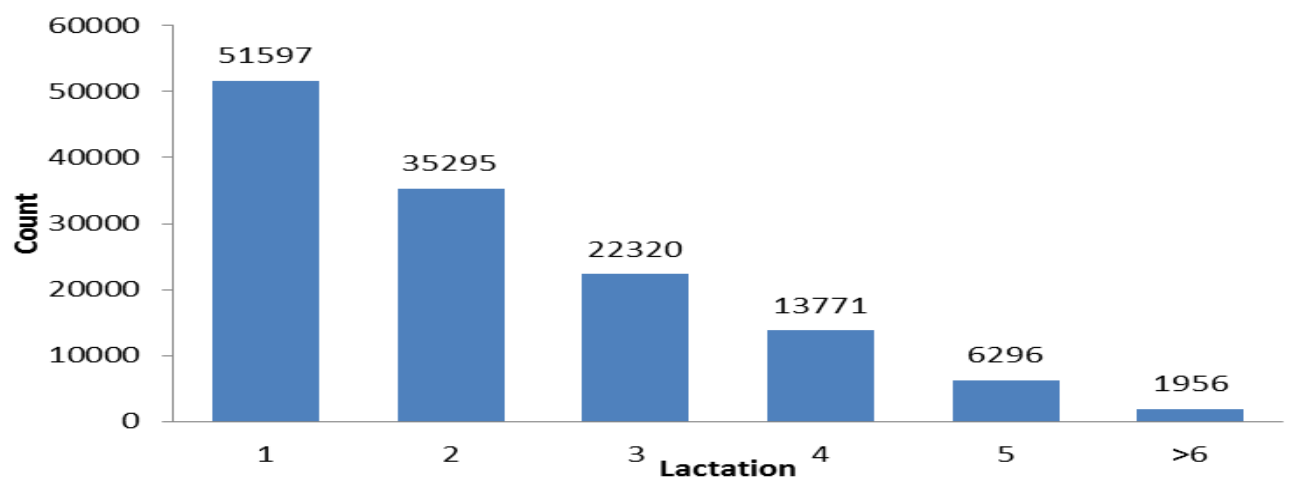

Fig.1. Count of closed lactations in Latvian brown cow population

In Latvian brown breed genetic ressources are included cows with at least $60 \%$ Latvian brown cow bloodiness with condition that in rest $40 \%$ there will be breeds which are close related to Latvian brown - Danish red or German red (Angler). Also there is condition about cow productivity - in most productive lactation milk yield should not be lower than $4000 \mathrm{~kg}$ and fat and protein content shouldnt be lower than breeds average.

Depending from Latvian brown cow bloodiness level in all breed structure we divided cows in 5 different groups (Table1) where fifth group were Latvian cow breed genetic ressources.

Table 1. Distribution groups based on Latvian brown cow breed bloodiness

\begin{tabular}{|c|c|c|}
\hline Group & Bloodiness of Latvian brown cows, \% & Number of cows \\
\hline 1 & $<30$ & 8254 \\
\hline 2 & $31-45$ & 20469 \\
\hline 3 & $46-60$ & 10850 \\
\hline 4 & $61-75$ & 2205 \\
\hline 5 & Genetic resources & 266 \\
\hline
\end{tabular}

The mathematical processing was performed using the SPSS program package.

To determine survival in different age at first calving were used Kaplan - Meier function.

To characterize diffrences between groups of age at first calving were used Bonfferoni test. Signifficant differences $(\mathrm{p}<0.05)$ in the tables were marked with different superscripted letters of alphabet $(\mathrm{A}, \mathrm{B}, \mathrm{C}$, etc.).

\section{RESULTS AND DISCUSSION}

Historically Latvian brown cow breed was most popular breed in country because of its good adjustment abilities and longer lifespan in herds, but in last 5 years Holstain black and white cows crowds out Latvian brown cows because of its higher milk productivity. (Data from Latvian data center) Latvian brown (LB) and Latvian blue cow breeds are 
the only ones that are included in Latvian cow genetic resources. Those cow breeds are not highly productive, but cow milk has higher milk dry matter content. Milk yield has tendency to increase as cows are getting older. Different studies show that cow productivity increases until $5^{\text {th }}$ lactation and then milk yield becomes stable (Baul et al., 2013). According by previous paper from Estonia, milk yield highest was observed in $2^{\text {nd }}$ lactation. Milk yield decreased in $3^{\text {rd }}$ and $4^{\text {th }}$ lactation, but increased in $5^{\text {th }}$ lactation. Fat content increased if milk yield decreased, the highest fat content (average $4.09 \%$ ) was observed in $4^{\text {th }}$ lactation when milk yield was $7472 \mathrm{~kg}$ (Saveli, Voore, 2006). Our research revealed highest values of fat content, compared with results of Estonia. It can be explained with fact that we found lower milk yields in lactation. Lower value of fat content $(3.94 \pm 0.01 \%)$ was found in $4^{\text {th }}$ lactation in our case, but lower value of protein content $(3.31 \pm 0.03 \%)$ in $6^{\text {th }}$ and older lactation (Table 2$)$.

Table 2. Milk productivity of Latvian brown cow population

\begin{tabular}{|c|c|c|c|}
\hline Lactation & Milk yield, kg & Fat content, $\%$ & Protein content, $\%$ \\
\hline 1 & $4826.1 \pm 5.44^{\mathrm{A}}$ & $4.88 \pm 0.01^{\mathrm{A}}$ & $4.25 \pm 0.01^{\mathrm{A}}$ \\
\hline 2 & $5394.4 \pm 7.50^{\mathrm{B}}$ & $4.34 \pm 0.01^{\mathrm{B}}$ & $3.86 \pm 0.01^{\mathrm{B}}$ \\
\hline 3 & $5702.9 \pm 9.44^{\mathrm{C}}$ & $4.03 \pm 0.01^{\mathrm{C}}$ & $3.67 \pm 0.01^{\mathrm{C}}$ \\
\hline 4 & $5873.6 \pm 11.95^{\mathrm{D}}$ & $3.94 \pm 0.01^{\mathrm{D}}$ & $3.36 \pm 0.01^{\mathrm{D}}$ \\
\hline 5 & $5891.8 \pm 17.24^{\mathrm{D}}$ & $4.04 \pm 0.02^{\mathrm{CE}}$ & $3.31 \pm 0.03^{\mathrm{E}}$ \\
\hline$>6$ & $5823.2 \pm 28.42^{\mathrm{D}}$ & $4.18 \pm 0.03^{\mathrm{E}}$ & \\
\hline ABCDE & \\
\hline
\end{tabular}

Latvian brown cow milk yield significantly lower $(\mathrm{p}<0.05)$ was in first lactation $(4826.1 \mathrm{~kg})$, but it increased until fifth lactation $(5891.8 \mathrm{~kg})$. Opposite situation was occurred with milk dry matter content, milk fat content significantly higher was in first lactation, but until $5^{\text {th }}$ lactation it decreased by $0.84 \%$, similar situation was occurred with milk protein content.

Nowadays Latvian brown and Latvian blue cow breeds are not purebred, but they have different breed bloodiness. Most common cross breeds are Danish red, Holstain red and white and Swedish red and white. According by scientists from Ireland, Holstein breed and crossbreeds with Holstein showed significantly highest milk yield compared with other breeds (Buckley et al., 2010). Mostly Holstein crossbreed cows are kept for intensive farming and fed with total mixed ration with high starch content in diet and it is the reason for milk yield increasing and fat content decreasing. This is one of main reasons why red cow breed in Latvian are still used in farms. Protein content can be affected by cow breed, diet, health and other factors (Baul et al., 2013) (Table 3).

Table 3. Different bloodiness Latvian brown cow productivity depending from dominant breed

\begin{tabular}{|l|c|c|c|}
\hline Dominant breed & Milk yield, kg & Fat content, $\%$ & Protein content, $\%$ \\
\hline Latvian brown & $4825.8 \pm 14.45^{\mathrm{A}}$ & $4.89 \pm 0.02$ & $4.31 \pm 0.02^{\mathrm{A}}$ \\
\hline Angeln & $4816.6 \pm 19.35^{\mathrm{A}}$ & $4.87 \pm 0.03$ & $4.27 \pm 0.03^{\mathrm{A}}$ \\
\hline Holstain black and white & $4822.9 \pm 19.10^{\mathrm{A}}$ & $4.90 \pm 0.03$ & $4.25 \pm 0.03^{\mathrm{A}}$ \\
\hline Swedish red and white & $4795.5 \pm 14.17^{\mathrm{A}}$ & $4.90 \pm 0.02$ & $4.29 \pm 0.02^{\mathrm{A}}$ \\
\hline Latvian blue & $4822.5 \pm 53.04^{\mathrm{A}}$ & $4.89 \pm 0.02$ & $4.20 \pm 0.02^{\mathrm{B}}$ \\
\hline Holstain red and white & $4843.6 \pm 12.86^{\mathrm{B}}$ & $4.87 \pm 0.02$ & $4.23 \pm 0.02^{\mathrm{A}}$ \\
\hline Danish red & $4826.0 \pm 10.75^{\mathrm{A}}$ & $4.90 \pm 0.02$ & $4.24 \pm 0.02^{\mathrm{A}}$ \\
\hline Swiss & $4887.3 \pm 26.37^{\mathrm{C}}$ & $4.11 \pm 0.04^{\mathrm{C}}$ \\
\hline ABC - traits with different subscriptions are significantly different $(\mathrm{p}<0.05)$ & $4.87 \pm 0.04$ & \\
\hline
\end{tabular}

Latvian brown cow breed is adapted to Latvian farming and climate conditions. The mixture of other breeds in Latvian brown blood gives ambiguous results - if Latvian brown blood level is lower than $30 \%$, cow productivity is significantly higher $(\mathrm{p}<0.05)$ than in other groups, the same situation was obtained with genetic resources and in cow group with LB bloodiness over $61 \%$ (average milk yield $5112 \mathrm{~kg}$ ). (Table 4)

Table 4. Cow with different Latvian brown bloodiness productivity

\begin{tabular}{|l|c|c|c|}
\hline Blodiness, \% & Milk yield, kg & Fat content, $\%$ & Protein content, $\%$ \\
\hline$<30$ & $5140.1 \pm 11.98^{\mathrm{A}}$ & $4.23 \pm 0.01^{\mathrm{A}}$ & $3.50 \pm 0.01^{\mathrm{A}}$ \\
\hline $31-45$ & $5109.7 \pm 7.61^{\mathrm{B}}$ & $4.17 \pm 0.01^{\mathrm{B}}$ & $3.53 \pm 0.01^{\mathrm{A}}$ \\
\hline $46-60$ & $5061.3 \pm 10.45^{\mathrm{B}}$ & $4.14 \pm 0.01^{\mathrm{B}}$ & $3.60 \pm 0.01^{\mathrm{B}}$ \\
\hline $61-75$ & $5112.5 \pm 23.04^{\mathrm{A}}$ & $4.19 \pm 0.01^{\mathrm{A}}$ & $3.60 \pm 0.02^{\mathrm{B}}$ \\
\hline Genetic resources & $5112.1 \pm 66.7^{\mathrm{A}}$ & $4.12 \pm 0.04^{\mathrm{B}}$ & $3.81 \pm 0.04^{\mathrm{C}}$ \\
\hline \multicolumn{4}{|l}{} \\
\hline
\end{tabular}

Milk fat content higher was in cow group with smallest amount of LB breed bloodiness, but in genetic resources group milk fat content was significantly lower than in other groups $(p<0.05)$. Milk protein on the other side had tendency increase together with LB breed blood amount, in comparison Genetic resources cow protein content is about $0.31 \%$ higher than in first cow group.

Average lifespan in LB cow population was 2463.0 days (in average 6.7 years or about 5 lactations). Depending from different amount of LB bloodiness in groups was obtained that greater risk being culled from herd is in cows with 
LB bloodiness less than $30 \%$, but genetic resources cows have longer life expectancy (Fig.2) In different studies was determined that red breed group cows is capable to live longer than black and white cow breed animals. (Dillon, Snijders, Buckley, 2003).

As were found scientists from US, when making a decision, the dairy farmer considers five major reasons: illness, low milk yield, conception status, stage of lactation, and parity. Culling potentially increases profits or reduces costs through the replacement of sick or open cows that are expensive to keep and may die or through the replacement of low yielding cows. Highest milk yield was protective against culling (Barkema et al., 1994; Grohn et al., 1998). In Tunisia more than $57 \%$ of cows are culled after the first two lactations and only $7.14 \%$ of them reached their fifth lactation. It means than average cows lifespan is only 2.6 lactations and cows can produce all potential. Dairy cow longevity is problem in many countries, because farmers mostly make a focus on the milk yield, they use more concentrate rations in cow diet and milk yield increases, but in connection with problems of problems and reproductive system. (Ajili et al., 2007). As were found scientists from Japan, the medium length of productive life of Holstein was about 1250 days (Terawaki et al., 2006). Similar results were found other scientists; average productive life of cows was 1951 days, but lifespan 4036 days. These parameters were different by different crossbreed and bloodiness cows groups (Effa et al., 2013).

Cow crossbreeding step and blood of each breed content determines maximal lifespan, productive life and lifetime productivity. In studies made in Russia was determined that lifespan of productive animals reduces about 1.7 lactations if red breed cows are crossbred with black and white cow breed animals (Kiselev, Novikov, Golikova, 2009).



Figure 2. Prognose of cumulative culling hazard risk in Latvian brown cow population

Growing young cows is very expensive ant it is keys why farmers needs to increased dairy cows productive life. Cow lifespan is depends from farm management, for example, age of first insemination and age of first calving, dry periods lactation length and other aspects. Dairy cows in Latvia have a big potential to increase lifespan. Latvian genetic resources are not suitable for intensive farming; indoor housing condition and high level concentrate diets. These cows are suitable for grazing systems and not so intensive farming. Latvian brown cow's milk is with good composition, it is suitable for cheese manufacturing and other perspectives. Genetic resources are environmental elements in landscape and it is necessary to save Latvian Brown and Latvian Blue cow population.

\section{CONCLUSIONS}

1. Significantly highest milk yield was observed in $5^{\text {th }}$ lactation $(5891.8 \pm 17.24 \mathrm{~kg} ; \mathrm{p}<0.05)$, fat and protein content was highest in $1^{\text {st }}$ lactation, respectively, $4.88 \pm 0.01 \%$ and $4.25 \pm 0.01 \%$.

2. Significantly highest milk yield grouped by breed was observed in group with Brown Swiss bloodiness $(4887.3 \pm 26.3 \mathrm{~kg} ; \mathrm{p}<0.05)$, but highest protein content in genetic resources group $(4.31 \pm 0.02 \%)$.

3. Average lifespan in LB cow population was 2463.0 days (in average 6.7 years or about 5 lactations

\section{REFERENCES}

1. Ajili, N., Rekik, B., Ben Gara, A., Bouraoui, R. 2007. Relationships among milk production, reproductive traits, and herd life for Tunisian Holstein-Friesian cows. African Journal of Agricultural Research, Vol. 2, pp. 47-51. 
2. Barkema, H. W., Westrik, J. D., Keulen, van K. A. S., Schukken, Y. H., Brand, A. 1994. The effects of lameness on reproductive performance, milk production and culling in Dutch dairy farms. Preventive Veterinary Medicine, Vol. 20, pp. $249-259$. http://dx.doi.org/10.1016/0167-5877(94)90058-2

3. Baul, S., Czsizter, L. T., Acatincai S., Cismas, T., Gavojdian, D., Tripon, I., Erina, S., Buzamat, G. 2013 Effect of Parity on Dynamics of Milk Yield and Composition during Normal Lactation in Dairy Cows. Animal Science and Biotechnologies, Vol. 46, Iss. 2 pp. 286-290.

4. Boscom, S. S., Young, A. Y. 1998. A Summary of the Reasons Why Farmers Cull Cows. Journal of Dairy Science 81, pp. 22992305. http://dx.doi.org/10.3168/jds.S0022-0302(98)75810-2

5. Buckley, F., Walsh, S., Dillon, P. 2010. Comparison of breed of dairy cow under grass-based spring milk production systems. Dairy production research Center.

6. Caraviello, D. Z., Weigel, K. A., Shook, G. E., Ruegg, P. L. 2005. Assessment of the Impact of Somatic Cell Count on Functional Longevity in Holstein and Jersey Cattle Using Survival Analysis Methodology. Journal of Dairy Science, Vol. 88, pp. 804-811. http://dx.doi.org/10.3168/jds.S0022-0302(05)72745-4

7. Cielava, L., Jonkus, D., Paura, L. 2014. Effect of farm szie on the productivity and longevity of Latvian Brown cows. Annual 20th International Scientific Conference Proceedings Research for Rural development, Vol. 1, 95-9, Latvia University of Agriculture.

8. Dillon P., Snijders S., Buckley F., Harris, B., O'Connor, P., Mee, J. F. 2003. A comparison of different dairy cow breeds on a seasonal grass-based system of milk production 2. Reproduction and survival. Livestock Production Science, Vol. 83, pp. 35-42. http://dx.doi.org/10.1016/S0301-6226(03)00042-3

9. Effa, K., Hunde, D., Shumiye, M., Silasie, R. H. 2013. Analysis of longevity traits and lifetime productivity of crossbred dairy cows in the Tropical Highlands of Ethiopia. Journal of Cell and Animal Biology, Vol. 7, pp. 138-143. http://dx.doi.org/10.5897/JCAB2013.0375

10. Grohn, Y. T., Eicker, S. W., Ducrocq, V., Hertl, J. A. 1998. Effect of Diseases on the Culling of Holstein Dairy Cows in New York State. Journal of Dairy Science, Vol. 81, pp. 966-978. http://dx.doi.org/10.3168/jds.S0022-0302(98)75657-7

11. Lucy, M.C. 2001. Reproductive Loss in High-Producing Dairy Cattle: Where Will It End? Journal of Dairy Science, Vol. 84, pp. 1277-1293. http://dx.doi.org/10.3168/jds.S0022-0302(01)70158-0

12. Penasa, M., Tiezzi, F., Sturaro, A., Cassandro, M., Marchi, M. De. 2014. A comparison of the predicted coagulation characteristics and composition of milk from multi-breed herds of Holstein-Friesian, Brown Swiss and Simmental cows. International Dairy Journal, Vol. 35, pp. 6-10. http://dx.doi.org/10.1016/j.idairyj.2013.10.004

13. Roxstrom, A., Strandberg, E. 2002. Genetic analysis of functional, fertility-, mastitis-, and production-determined length of productive life in Swedish dairy cattle. Livestock Production Science, Vol. 74, pp. 125-135. http://dx.doi.org/10.1016/S0301$\underline{6226(01) 00300-1}$

14. Saveli, O., Voore, M. 2006. Milk productivity of dairy cows in Estonia. proceedings of the 12th Baltic animal breeding conference, Vol. 1, pp. 13 - 20, Ministry of Agriculture of the Republic of Latvia.

15. Sklan, D., Kaim, M., Moallem, U., Folamn, Y. 1994 Effect of Dietary Calcium Soaps on Milk Yield, Body Weight, Reproductive Hormones, and Fertility in First Parity and Older Cows. Journal of Dairy Science, Vol. 77, pp. 1652-1660. http://dx.doi.org/10.3168/jds.S0022-0302(94)77107-1

16. Terawaki, Y., Katsumi, T., Ducrocq, V. 2006. Development of a Survival Model with Piecewise Weibull Baselines for the Analysis of Length of Productive Life of Holstein Cows in Japan. Journal of Dairy Science, Vol. 89, pp. 4058-4065. http://dx.doi.org/10.3168/jds.S0022-0302(06)72449-3

17. Vries de A. 2008. Productive Life Of Dairy Cows In Florida. Avaiable at : http://dairy.ifas.ufl.edu/dpc/2003/deVries.pdf

18. Yu, A. B., Zhao, G. Q., Huo, Y. J. 2011. Relationship Between Parity and Cellular Composition of Somatic Cells in Milk of Chinese Holstein Cows. Journal of Animal and Veterinary Advances, Vol. 10, pp. $2067-2073$. http://dx.doi.org/10.3923/javaa.2011.2067.2073 